\title{
Deficiency of the Survival of Motor Neuron Protein Impairs mRNA Localization and Local Translation in the Growth Cone of Motor Neurons
}

\author{
Claudia Fallini, ${ }^{1 \star}$ Paul G. Donlin-Asp, ${ }^{1 \star}$ Jeremy P. Rouanet, ${ }^{1}$ Gary J. Bassell, ${ }^{1,2}$ and Wilfried Rossoll ${ }^{1}$ \\ ${ }^{1}$ Department of Cell Biology and 'Department of Neurology, Emory University School of Medicine, Atlanta, Georgia 30322
}

\begin{abstract}
Spinal muscular atrophy (SMA) is a neurodegenerative disease primarily affecting spinal motor neurons. It is caused by reduced levels of the survival of motor neuron (SMN) protein, which plays an essential role in the biogenesis of spliceosomal small nuclear ribonucleoproteins in all tissues. The etiology of the specific defects in the motor circuitry in SMA is still unclear, but SMN has also been implicated in mediating the axonal localization of mRNA-protein complexes, which may contribute to the axonal degeneration observed in SMA. Here, we report that SMN deficiency severely disrupts local protein synthesis within neuronal growth cones. We also identify the cytoskeleton-associated growth-associated protein 43 (GAP43) mRNA as a new target of SMN and show that motor neurons from SMA mouse models have reduced levels of GAP43 mRNA and protein in axons and growth cones. Importantly, overexpression of two mRNAbinding proteins, HuD and IMP1, restores GAP43 mRNA and protein levels in growth cones and rescues axon outgrowth defects in SMA neurons. These findings demonstrate that SMN plays an important role in the localization and local translation of mRNAs with important axonal functions and suggest that disruption of this function may contribute to the axonal defects observed in SMA.
\end{abstract}

Key words: GAP43; local translation; motor neuron; RNA trafficking; SMA; SMN

\section{Significance Statement}

The motor neuron disease spinal muscular atrophy (SMA) is caused by reduced levels of the survival of motor neuron (SMN) protein, which plays a key role in assembling RNA/protein complexes that are essential for mRNA splicing. It remains unclear whether defects in this well characterized housekeeping function cause the specific degeneration of spinal motor neurons observed in SMA. Here, we describe an additional role of SMN in regulating the axonal localization and local translation of the mRNA encoding growth-associated protein 43 (GAP43). This study supports a model whereby SMN deficiency impedes transport and local translation of mRNAs important for neurite outgrowth and stabilization, thus contributing to axon degeneration, muscle denervation, and motor neuron cell death in SMA.

\section{Introduction}

Spinal muscular atrophy (SMA) is a neurodegenerative disease characterized by progressive denervation of skeletal muscles, which results in muscle weakness, paralysis, and death due to

\footnotetext{
Received June 22, 2015; revised Feb. 23, 2016; accepted Feb. 25, 2016.

Author contributions:C.F., G.J.B., and W.R. designed research; C.F., P.G.D.-A., and J.P.R. performed research; C.F., P.G.D.-A., J.P.R., G.J.B., and W.R. analyzed data; C.F. and W.R. wrote the paper.

This work was supported by Families of SMA/Cure SMA (W.R. and C.F.); the Muscular Dystrophy Association and the Weisman Family Foundation (G.J.B.); the National Institutes of Health (Grant NS091749 to W.R.); the National Research Service (Training Grant F31NS084730-01), and the Achievement Rewards for College Scientists Foundation (Roche Foundation Award to P.G.D.-A.). We thank Lian Li and Latoya Rowe for excellent technical support.

The authors declare no competing financial interests.

*C.F. and P.G.D.-A., contributed equally to this work.

Correspondence should be addressed to either Wilfried Rossoll, PhD, or Gary J. Bassell, PhD, Emory University School of Medicine, Whitehead Biomedical Research Building, Room 415, 615 Michael St NE, Atlanta, GA, E-mail: wrossol@emory.edu or gbassel@emory.edu.

DOI:10.1523/JNEUROSCI.2396-15.2016

Copyright $\odot 2016$ the authors $\quad 0270-6474 / 16 / 363811-10 \$ 15.00 / 0$
}

respiratory failure (Crawford and Pardo, 1996). The primary pathology in SMA is a developmental neuromuscular junction (NMJ) synaptopathy (Kariya et al., 2008; Dupuis and EchanizLaguna, 2010) followed by degeneration of motor neurons. Axonal degeneration precedes motor neuron death (Monani et al., 2000; Cifuentes-Diaz et al., 2002) and defects at the NMJ are the earliest events detected in SMA mouse models (Murray et al., 2008; Ling et al., 2010; Ling et al., 2012; Martinez et al., 2012; Goulet et al., 2013; Ruiz and Tabares, 2014).

The molecular defect causing SMA is a reduction in the levels of the survival of motor neuron (SMN) protein due to mutations in the SMN1 gene locus (Lefebvre et al., 1995). However, the downstream molecular pathways leading to motor neuron degeneration are still unknown. SMN is a ubiquitously expressed protein with a well characterized essential function in the assembly of small nuclear ribonucleoproteins (snRNPs), the key components of spliceosomes (Gubitz et al., 2004; Battle et al., 2006; 
Coady and Lorson, 2011; Workman et al., 2012). Recent studies have shown that, beyond its role in snRNP assembly, SMN is essential for the biogenesis of U7 snRNPs and 3'-end formation of histone mRNAs (Tisdale et al., 2013) and may have a more general role as a molecular chaperone for the assembly of various RNP complexes (Friesen and Dreyfuss, 2000; Brahms et al., 2001; Azzouz et al., 2005; Pellizzoni, 2007; Boulisfane et al., 2011; Lotti et al., 2012; Li et al., 2014). In particular, SMN has been suggested to play a role in regulating the localization of mRNAs and mRNA-binding proteins (mRBPs) in axons (Akten et al., 2011; Fallini et al., 2011; Hubers et al., 2011; Sanchez et al., 2013; Fallini et al., 2014). The mislocalization of $\beta$-actin mRNA in SMA motor neurons was the first example (Rossoll et al., 2003); however, tissue-specific deletion of the $\beta$-actin locus in motor neurons did not affect their survival nor the formation and maintenance of the NMJ (Cheever et al., 2011). This observation suggests that deficiency of multiple mRNAs may underlie SMA pathogenesis, which is consistent with our previous report of deficient poly(A) mRNA localization in the axon of SMN-depleted motor neurons (Fallini et al., 2011) and recent RNAseq analysis of axonal mRNAs in SMA motor neurons (Saal et al., 2014). Defects in mRNA localization are accompanied by a similar decrease in axonal levels of the SMN-interacting mRBPs HuD and IMP1 (Fallini et al., 2011; Fallini et al., 2014). IMP1, also known as zipcode binding protein 1 (ZBP1), is a KH domain RNA-binding protein required for the localization and local translation of several mRNAs, including $\beta$-actin and growth-associated protein 43 (GAP43) mRNA (Donnelly et al., 2013). IMP1 associates in actively transported RNA granules with the ELAV-like RNAbinding protein $\mathrm{HuD}$ and cooperatively regulates the stability and axonal localization of Tau and GAP43 mRNA (Atlas et al., 2007; Yoo et al., 2013). HuD and GAP43 mRNA colocalize in RNA granules within axons and growth cones (Smith et al., 2004). SMN interaction with $\mathrm{HuD}$ was previously shown to play a role in neuritin/cpg15 mRNA localization, which is altered in SMA (Akten et al., 2011).

In this study, we first show that the reduction of poly(A) mRNA levels in SMA axons directly results in deficiency of axonal protein synthesis. We identify GAP43 as an mRNA that is reduced and mislocalized in SMA motor neurons and test the hypothesis that impairments in axonal localization of GAP43 mRNA and protein plays a role in SMA. Our results show that reduced GAP43 mRNA and protein levels in SMA motor neuron growth cones can be restored by increasing the expression of two regulatory mRBPs, HuD and IMP1, which is sufficient to rescue the impairment in axon outgrowth observed in SMA motor neurons. Together, these findings support a model of dysregulated local translational as a contributing mechanism to SMA pathogenesis.

\section{Materials and Methods}

Motor neuron culture and transfection. Primary motor neurons from wild-type (WT) and SMA (Smn ${ }^{-1-}$; $h$ SMN2; stock number \#005024; Jackson Laboratories) embryonic day 13.5 (E13.5) mouse embryos of either sex were isolated, cultured, and transfected by magnetofection as described previously (Fallini et al., 2010; Fallini et al., 2011). Cells were fixed at 3-5 d in vitro ( DIV) or 2-3 d after transfection as indicated, and processed for quantitative FISH (Q-FISH) or immunostaining. Monomeric green (GFP) or red (mCherry) fluorescent proteins were fused to murine SMN (Fallini et al., 2010), human HuD (Fallini et al., 2011), and rat IMP1 (Fallini et al., 2014) cDNAs. A flexible linker [(SGGG)3] was inserted between all the fusion partners to facilitate correct protein folding. The pGIPZ shRNA vectors targeting SMN sequence (shSMN) and a nonsilencing control (shCtrl, RHS4346) were obtained from Open Biosystems (Fallini et al., 2011). For axon length analysis, cells were trans- fected with GFP alone to label the whole axon and to identify individual cells.

FISH and immunofluorescence. Motor neurons were fixed for 15 min with $4 \%$ paraformaldehyde in PBS. FISH was performed as described previously (Fallini et al., 2011) with some modifications. Briefly, fixed motor neurons were rinsed in PBS containing $5 \mathrm{~mm} \mathrm{MgCl}_{2}$ and equilibrated in $1 \times$ SSC buffer for $10 \mathrm{~min}$. Cells were then washed in $10 \%$ formamide (Sigma-Aldrich) for $10 \mathrm{~min}$ before preincubation in hybridization buffer $(20 \%$ dextran sulfate, $4 \times$ SSC, $4 \mathrm{mg} / \mathrm{ml} \mathrm{BSA,} 20 \mathrm{~mm}$ ribonucleoside vanadyl complex, and $10 \mathrm{~mm}$ sodium phosphate buffer, $\mathrm{pH}$ $7.0)$ at $37^{\circ} \mathrm{C}$ for $1.5 \mathrm{~h}$. Probes $(1 \mu \mathrm{l})$ were resuspended with $10 \mu \mathrm{g}$ each of E. coli tRNA and salmon sperm DNA in $50 \mu \mathrm{l}$ of hybridization buffer and incubated with the coverslips at $37^{\circ} \mathrm{C}$ overnight. Stellaris FISH probes for GAP43 and $\beta$-actin directly labeled with Quasar570 and Quasar670, respectively, were obtained from Biosearch Technologies. A Cy3-labeled oligo dT probe (Biosearch Technologies) was used to detect poly(A)positive mRNAs. The specificity of the probes was demonstrated using a GFP control probe (see Fig. 4C). For immunofluorescence assays, fixed motor neurons were incubated overnight at $4^{\circ} \mathrm{C}$ with GAP43 (Epitomics, 1:250) and SMN (BD Biosciences, 1:500) antibodies in blocking buffer (5\% BSA, $1 \times$ PBS). Cy3-, Cy2-, or Cy5-conjugated secondary antibodies (Jackson Immunoresearch) were incubated for $1 \mathrm{~h}$ at room temperature.

Image acquisition and analysis. For high-resolution imaging, a $60 \times$ objective (1.4 numerical aperture) was used. $Z$-series (5-10 sections, 0.2 $\mu \mathrm{m}$ thickness) were acquired with an epifluorescence microscope (Ti; Nikon) equipped with a cooled CCD camera (HQ2; Photometrics). For low-magnification imaging, a $10 \times$ or $20 \times$ phase objective was used and single optical slices were acquired. $Z$-stacks were deconvolved (Autoquant X2; Media Cybernetics) and analyzed using Imaris software (Bitplane). For the analysis of fluorescence intensity, a $70-80 \mu \mathrm{m}$ segment of the axon starting $20 \mu \mathrm{m}$ from the cell body was analyzed. Background fluorescence was subtracted in all channels and an additional threshold was applied to discriminate between signal and noise. Axon length measurements were performed as described previously (Fallini et al., 2012b).

Protein extraction and Western blot. Brain and spinal cord tissue isolated from E12 mouse embryos of either sex was homogenized in lysis buffer (50 mm Tris- $\mathrm{HCl}, 150 \mathrm{~mm} \mathrm{NaCl}, 2 \%$ Triton X-100, protease inhibitors) and sonicated on ice $3 \times 10 \mathrm{~min}$. Proteins were separated on a $10 \%$ polyacrylamide-SDS gel and hybridized with primary antibodies directed against SMN (BD Bioscience, 1:500), GAP43 (Epitomics, 1:500), actin (Sigma-Aldrich, 1:1000), and tubulin (Sigma-Aldrich, 1:1000). IRDye-conjugated secondary antibodies (LI-COR) were used for detection. The intensity of the protein bands was quantified using ImageJ.

Metabolic labeling of newly synthesized proteins with AHA. Primary E18 cortical neurons were transfected via nucleofection (Lonza) with either shCtrl or shSMN plasmids and plated in PDMS microfluidic chambers (Xona) mounted on poly-D lysine-coated cover glass. Cells were grown until axons crossed into the axonal chamber (DIV4), and methioninefree DMEM (Invitrogen) supplemented with B27 was then added to both the axonal and cell body compartments for $1 \mathrm{~h}$. After methionine starvation, $2 \mathrm{~mm}$ L-azidohomoalanine(AHA) was added to only the cell body or axonal compartment to restrict AHA labeling locally and spatially to individual compartments with or without $40 \mu \mathrm{M}$ anisomycin to inhibit protein synthesis. Media volume was higher in compartments without AHA added to prevent diffusion of AHA. Cells were washed and fixed after $2 \mathrm{~h}$ and AHA incorporation was detected with Alexa Fluor 647conjugated alkyne using Click-iT chemistry (Invitrogen) according to the manufacturer's recommendations.

Statistical analysis. Experimental data were analyzed for statistical significance using the Prism 6 (GraphPad) software. Individual values were normalized to the mean of the control sample (e.g., WT cells) and measurements from at least three individual experiments were pooled together. For normally distributed data, Student's $t$ test or one-way ANOVA with Dunnet's post hoc test were used. For axon length analysis, axon measurements from each individual experiment were normalized to the mean of the control sample (i.e., WT cells) and values from four separate experiments were pooled together. The distribution of the data across the whole population was analyzed using cumulative frequency plots that display the frequency of occurrence ( $y$-axis) of axonal length values ( $x$-axis) that were equal to or less 

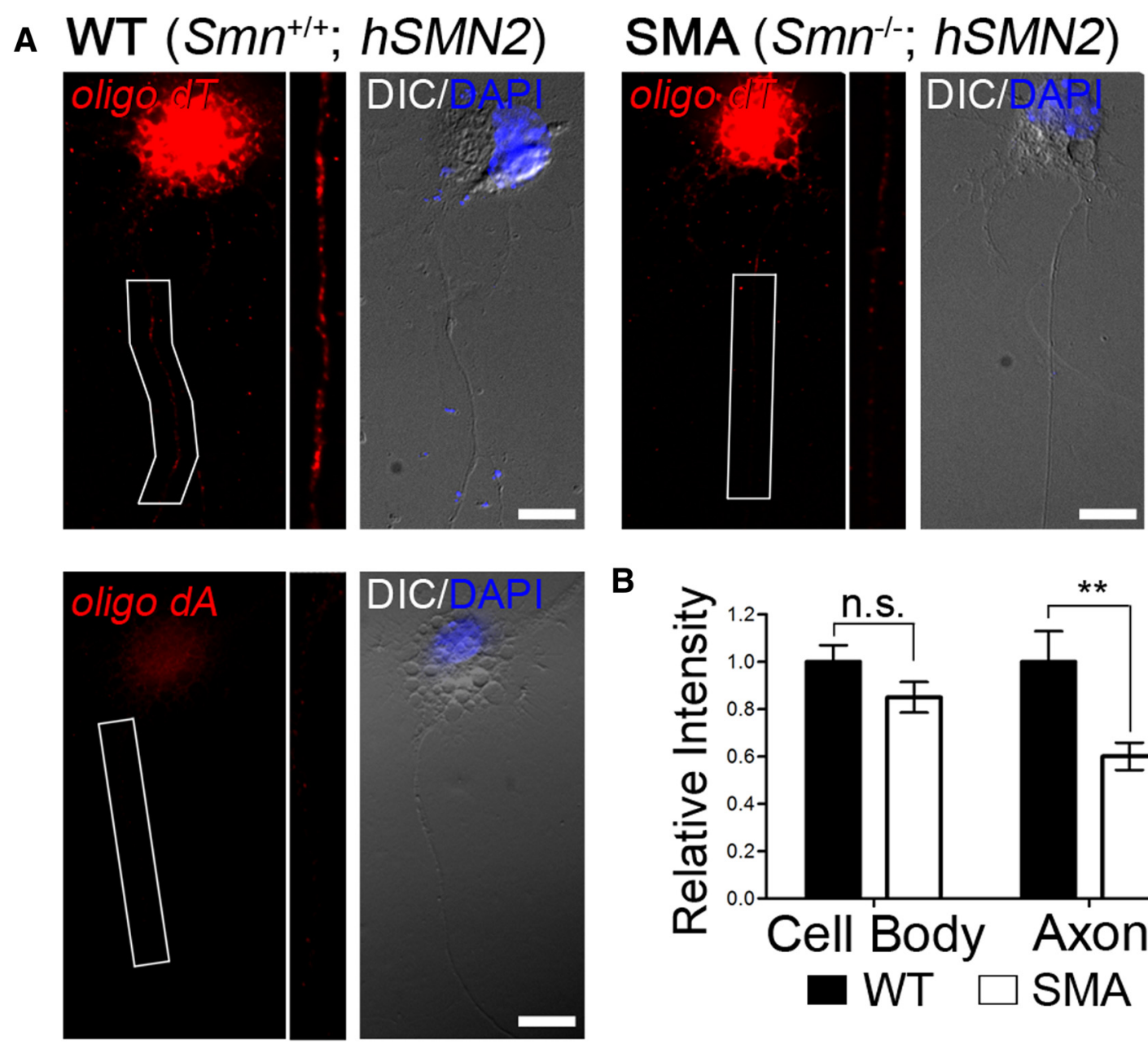

B

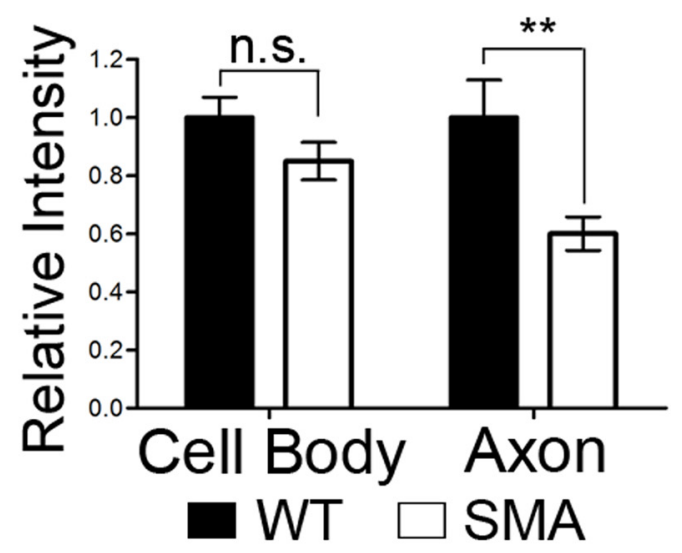

Figure 1. SMA motor neurons have reduced levels of axonal poly(A) mRNAs. A, Motor neurons isolated from SMA and WT embryos were hybridized with an oligo dT probe to detect poly(A) mRNAs. An oligo dA probe was used as a negative control. Scale bar, $10 \mu \mathrm{m}$. $\boldsymbol{B}$, Fluorescence intensity of the FISH signal in the cell body and axon was quantified and compared between WT and SMA cells. A significant reduction was observed in the axon, whereas no difference was detected in the cell body. Error bars indicate mean \pm SEM (Student's $t$ test; $n=40$ cells from three independent experiments; ${ }^{* *} p<0.01$; ns, not significant).

than a reference value. The Kolmogorov-Smirnov test was used to determine whether the distributions from the different conditions were significantly different from the control population (i.e., WT). For all analyses, significance was defined as $p<0.05$.

\section{Results}

SMN deficiency affects mRNA distribution and translation at the growth cone

Deficiency of SMN protein in shRNA-treated motor neurons (Fallini et al., 2011) and motor neurons derived from an SMA mouse model have significantly reduced poly(A) mRNA content in the axons, but not in the cell bodies (Fig. 1). This observation led us to hypothesize that reduced axonal transcript levels may cause a compartmentalized reduction in local protein translation. To test this hypothesis, cortical neurons that readily grow and project axons across compartmentalized microfluidic chambers were transfected with shRNA vectors to knock down SMN protein expression (shSMN; Fig. 2A, B; Fallini et al., 2011). Newly synthesized proteins in the cell body or growth cone compartment were detected using FUNCAT (fluorescent noncanonical amino acid tagging; Tom Dieck et al., 2012). The methionine analog AHA was added to either the cell body or the axon side for metabolic labeling. Click chemistry was used to fluorescently tag the incorporated AHA and newly synthesized proteins were quantified using high-resolution fluorescence microscopy. Whereas no effect was observed on overall protein synthesis in the cell soma, a $60 \%$ reduction in the levels of AHA-labeled proteins was detected in neuronal growth cones (Fig. 2C-E). Although we cannot exclude that subtle changes in the translational levels in the cell soma were masked due to the abundance of newly synthesized proteins, these data suggest no global change in protein synthesis, but rather more spatially restricted local changes distally possibly due to defective mRNA localization. Together, these results demonstrate that SMN deficiency leads to defective mRNA localization and consequent impairment in local protein synthesis in the distal axon, thus possibly contributing to the axonal phenotype in SMA.

\section{GAP43 mRNA is mislocalized in SMA motor neurons}

The axon outgrowth defect in SMA motor neurons suggests the involvement of other transcripts in addition to $\beta$-actin because axonally synthesized $\beta$-actin is mostly associated with axonal branching rather than elongation (Donnelly et al., 2013). Therefore, we investigated whether axon-growth-promoting mRNAs are mislocalized in SMA motor neurons. In particular, we focused on GAP43 mRNA, a known target of the mRBPs HuD and IMP1. Two cellular models were used to assess the effects of SMN 


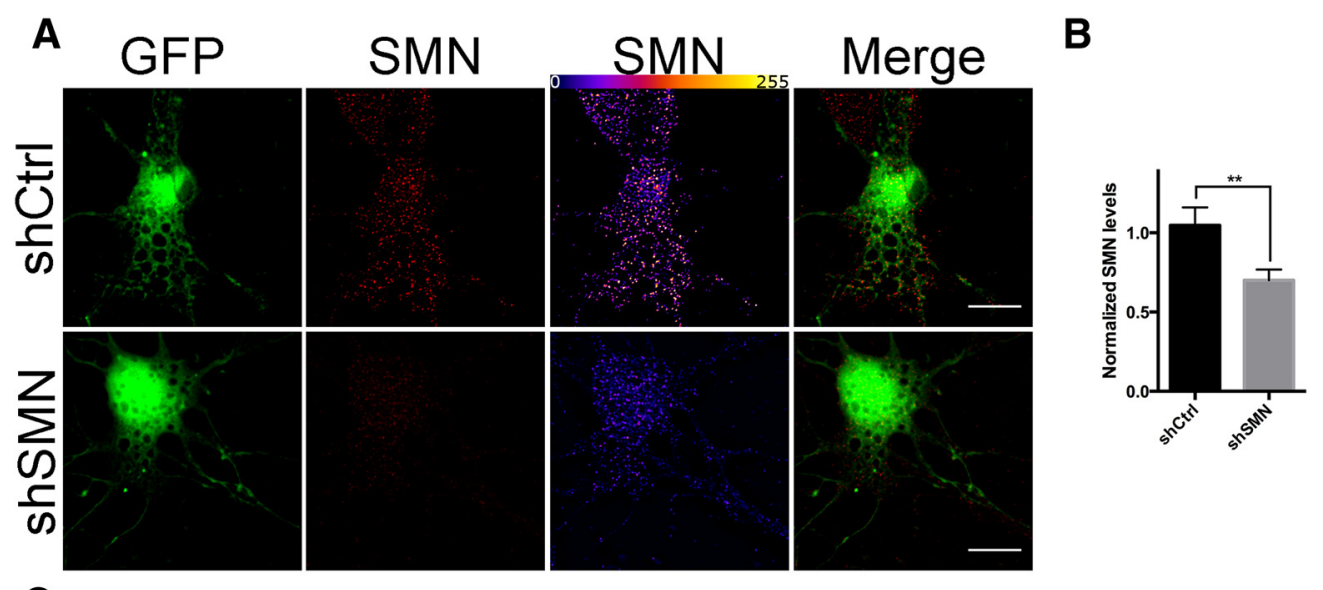

C

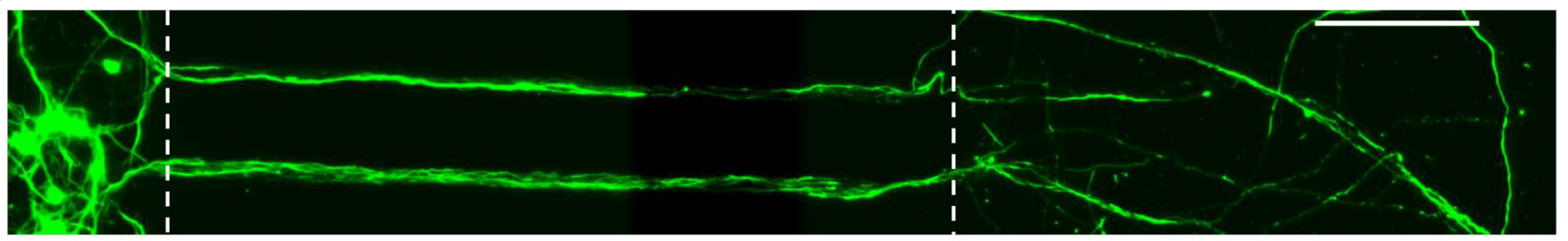

D

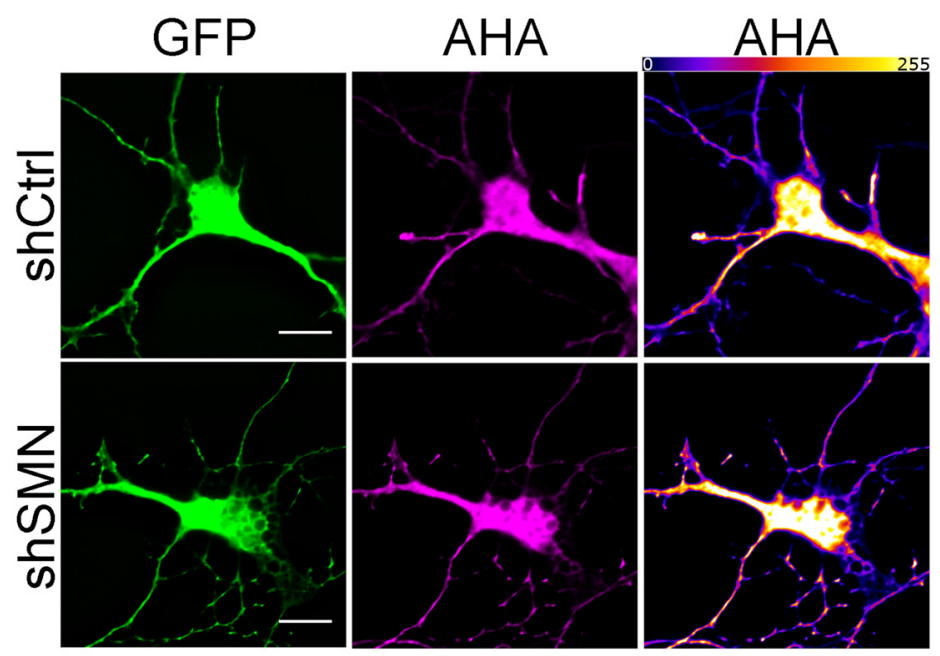

E

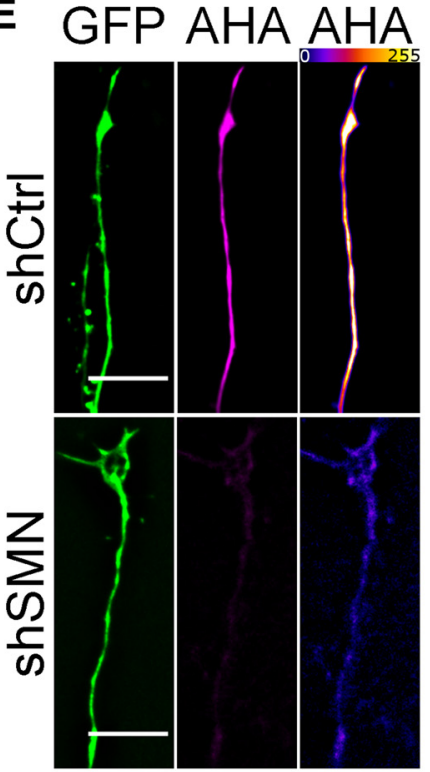

$\mathbf{F}$

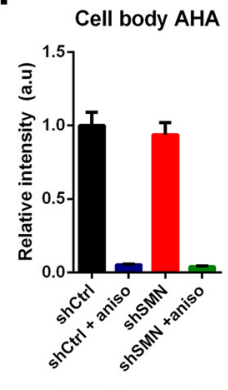

Growth cone AHA

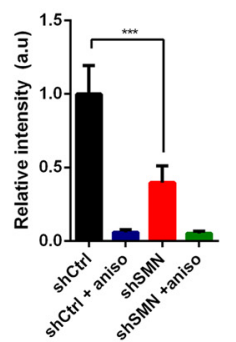

Figure 2. SMN deficiency causes reduced local protein synthesis in axonal growth cones. $\boldsymbol{A}, \boldsymbol{B}$, SMN knock-down efficiency (red) was quantified in cortical neurons transfected with an shRNA directed against SMN (shSMN) versus control cells (shCtrl). GFP (green) was used to identify transfected cells. Error bars indicate mean \pm SEM (Student's $t$ test, $n=>30$ cells/condition from three independent experiments, $\left.{ }^{* *} p<0.001\right)$. Cells in $\boldsymbol{A}, \boldsymbol{D}$, and $\boldsymbol{E}$ are also displayed as a pseudocolored heat map of pixel intensity, with warm colors denoting higher signal ( $\left.0-255\right)$. Scale bar, $10 \mu \mathrm{m}$. C, Cortical neurons grown in microfluidic chambers stained for tubulin. Scale bar: $100 \mu \mathrm{m} . \boldsymbol{D}, \boldsymbol{E}$, The methionine analog AHA was added to either the cell body or the axon side for metabolic labeling. SMN depletion leads to decreased incorporation of AHA in growth cones $(\boldsymbol{E})$ of cortical neurons with no change in the cell bodies $(\boldsymbol{D})$. Scale bar, $10 \mu \mathrm{m}$. $\boldsymbol{F}$, Quantification of AHA staining in the cell body and growth cone from shCtrl and shSMN neurons in the presence or absence of anisomycin to block protein synthesis. Error bars indicate mean \pm SEM (one-way ANOVA with Dunnet's post hoc test, $n=>30$ cells/condition from three independent experiments, $\left.{ }^{* *} p<0.001\right)$.

deficiency on GAP43 mRNA and protein localization: (1) WT motor neurons in which SMN levels were acutely reduced by shRNA and (2) motor neurons isolated from SMA mouse embryos (E13.5; Smn ${ }^{-1-} ;$ hSMN2) that have chronically low amounts of full-length SMN protein. The localization and abundance of GAP43 and $\beta$-actin mRNAs were assessed by Q-FISH. A striking reduction in the levels of both mRNAs was observed in the axons and growth cones of shSMN-transfected motor neurons $5 \mathrm{~d}$ after transfection (Fig. 3). No difference was detected in the cell bodies. Similarly, after 3 DIV, motor neurons obtained from SMA mouse embryos showed a $26 \%$ and $28 \%$ reduction, respectively, in the levels of GAP43 and $\beta$-actin mRNAs in the proximal axonal segment compared with WT $\left(S m n^{+/+} ;\right.$hSMN2) controls (Fig. 4). A clear trend toward reduction was detected in SMA growth cones (GAP43: $0.70 \pm 0.17 ; \beta$-actin: $0.64 \pm 0.07$ ), although it did not reach statistical significance, and no difference was observed in the cell body. However, when motor neurons were analyzed at $5 \mathrm{DIV}$, the levels of GAP43 and $\beta$-actin mRNAs were significantly reduced also in the cell body by $26 \%$ and $25 \%$, respectively (Fig. $4 E$ ). These results suggest that the general reduction of GAP43 and $\beta$-actin mRNA levels in cell bodies is subsequent to the early axonal localization defect. 
A shCtrl
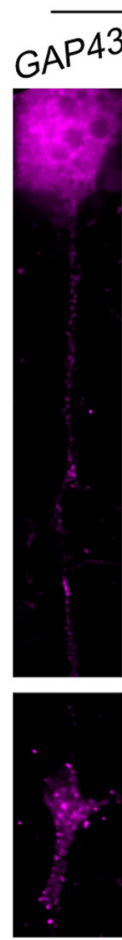
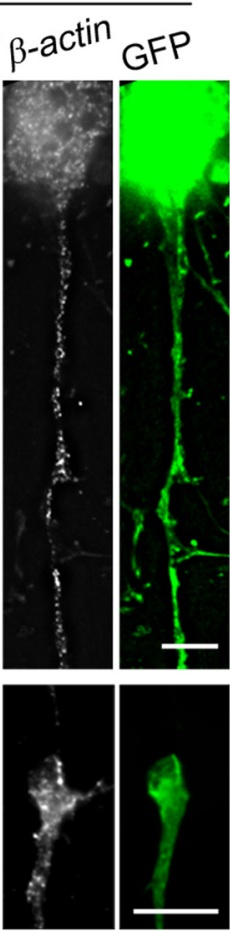

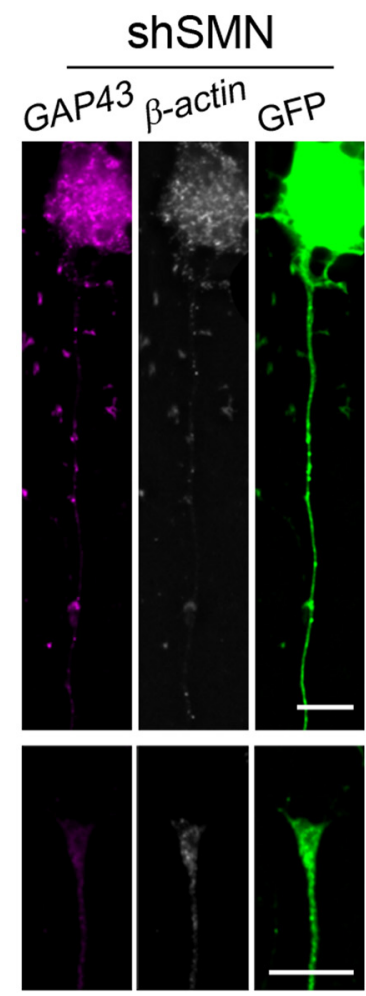

B
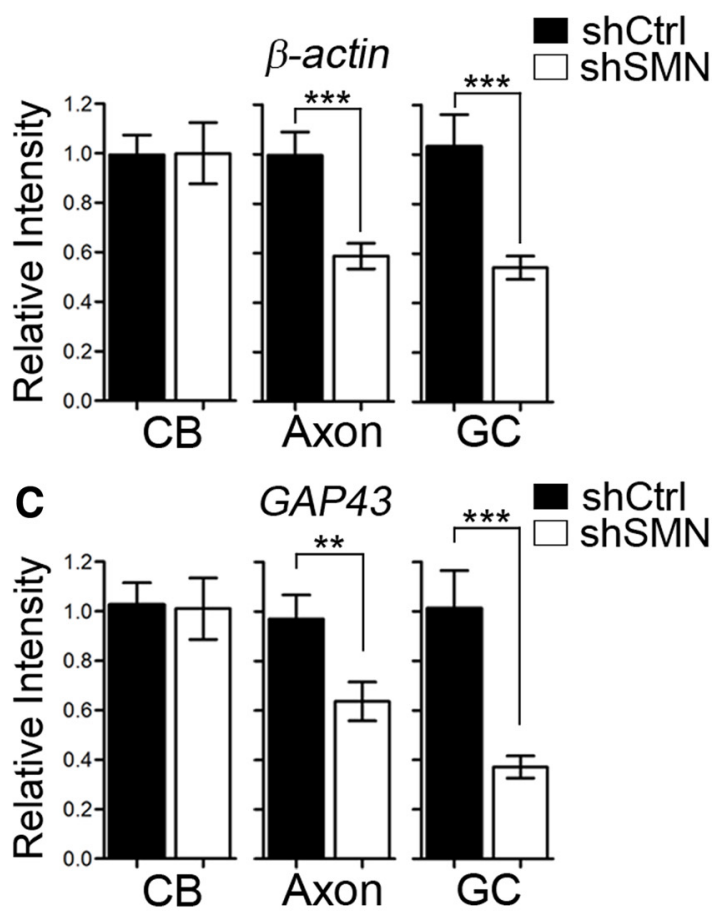

Figure 3. GAP43 and $\beta$-actin mRNAs are reduced in axons and growth cones of SMN deficient motor neurons. $A$, Primary motor neurons were transfected with an shRNA construct directed against SMN (shSMN) or a control vector (shCtrl). Five days after transfection, cells were fixed and hybridized with probes specific for GAP43 (magenta) and $\beta$-actin (white) mRNA. GFP (green) identifies transfected cells. Scale bar, $10 \mu \mathrm{m} . B, C$, Fluorescence intensity was quantified in the cell body, axon, and growth cone and compared between shSMN and shCtrl cells. A significant reduction in both GAP43 ( $C$ and $\beta$-actin $(\boldsymbol{B})$ mRNA levels was observed in the axon and growth cone. Error bars indicate mean \pm SEM (Student's $t$ test; $n=30$ cells from three independent experiments; ${ }^{* *} p<0.01$, $\left.*^{* *} p<0.001\right)$. Scale bar, $10 \mu \mathrm{m}$.

GAP43 protein is reduced in SMA growth cones

To investigate whether a reduction in GAP43 mRNA levels in the axon of SMA motor neurons is associated with a similar decrease in the levels of GAP43 protein, we performed quantitative immunofluorescence in primary motor neurons isolated from SMA embryos. We found that GAP43 mRNA decreased localization is sufficient to reduce its protein levels at the growth cone (Fig. $5 A, B)$. SMA motor neurons at $3 \mathrm{DIV}$, when no reduction of GAP43 mRNA levels is observed in the cell body, showed significantly lower levels of GAP43 protein at the growth cone compared with WT cells $(0.69 \pm 0.07$ SMA vs $1.0 \pm 0.12 \mathrm{WT})$, whereas a nonsignificant $39 \%$ increase in the cell body was detected. At 5 DIV, GAP43 protein levels were reduced also in the cell body (data not shown). Similar results were observed in shSMN-transfected motor neurons (Fig. 5C,D). However, no difference in GAP43 protein levels was detected in whole-brain and spinal cord lysates by Western blotting (Fig. 5E). These data suggest that SMN is important for the axonal localization of GAP43 mRNA and protein, which, in the absence of SMN, are retained in the cell body and eventually degraded. A similar mild reduction in the overall mRNA levels associated with a more dramatic decrease in the axonal localization was observed for the SMNassociated mRNAs Anxa2a and Cox4i2 (Rage et al., 2013).

\section{Overexpression of IMP1 and HuD rescues GAP43} axonal deficiency

Because GAP43 mRNA stability, transport, and translation are controlled by the mRBPs HuD and IMP1 (Yoo et al., 2013), the expression of which is reduced in SMA motor neurons, we hypothesized that restoring the levels of these mRBPs could rescue the reduction of GAP43 levels at the axon tip. To test this possibility, we expressed GFP-tagged HuD and IMP1 in SMA motor neurons and quantified GAP43 protein levels $2 \mathrm{~d}$ after transfection (Fig. 6A). Under these conditions, we observed a significant increase in GAP43 protein at the growth cone to levels similar to WT cells $(0.73 \pm 0.09$ GFP-HuD, $0.97 \pm 0.18$ GFP-IMP1 vs $1 \pm$ $0.13 \mathrm{WT})$. Importantly, the rescue of GAP43 protein levels due to $\mathrm{HuD}$ and IMP1 expression was associated with a parallel increase in the levels of GAP43 mRNA (0.92 \pm 0.16 GFP-HuD, $1.19 \pm$ 0.16 GFP-IMP1 vs $1.00 \pm 0.09$ WT; Fig. $6 B$ ), suggesting that overexpression of these mRBPs is sufficient to enhance GAP43 mRNA transport and local translation. Because GAP43 acts as a positive regulator of axon outgrowth and growth cone stability, we investigated whether the rescue of GAP43 protein levels by IMP1 and $\mathrm{HuD}$ expression could also restore axon growth in SMA motor neurons. SMA motor neurons were transfected with fluorescently tagged mRBPs and the length of the main axon branch was measured $2 \mathrm{~d}$ after transfection. Although SMA motor neurons had significantly shorter axons compared with WT cells, the expression of mCherry-tagged HuD or IMP1 was able to fully rescue the axonal defect (Fig. 6C). Together, these results suggest that the reduction in the mRNA and protein levels of GAP43, and possibly other HuD/IMP1 targets in the axons and growth cones of SMA motor neurons, contribute to the axonal defects that characterize SMA pathology.

\section{Discussion}

The role of SMN as a spliceosome assembly factor has been characterized extensively (Gubitz et al., 2004; Battle et al., 2006; Coady and Lorson, 2011; Workman et al., 2012). However, the evidence 

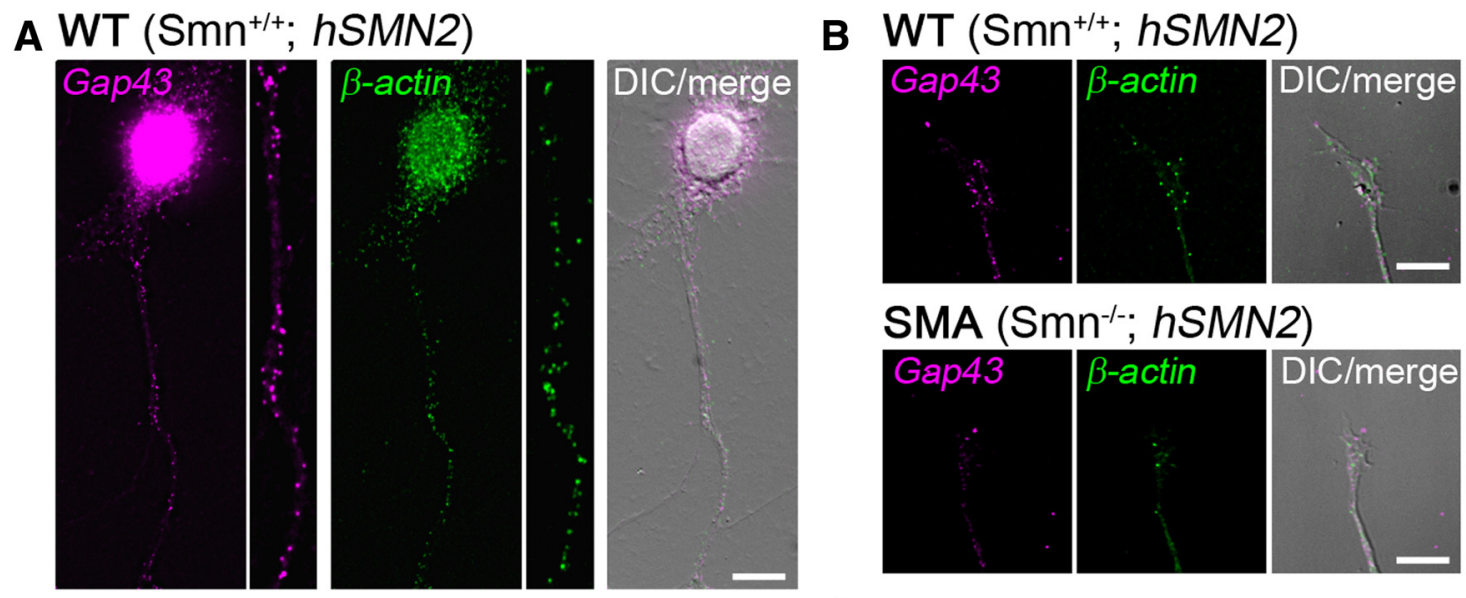

SMA (Smn ${ }^{-1-;}$ hSMN2)
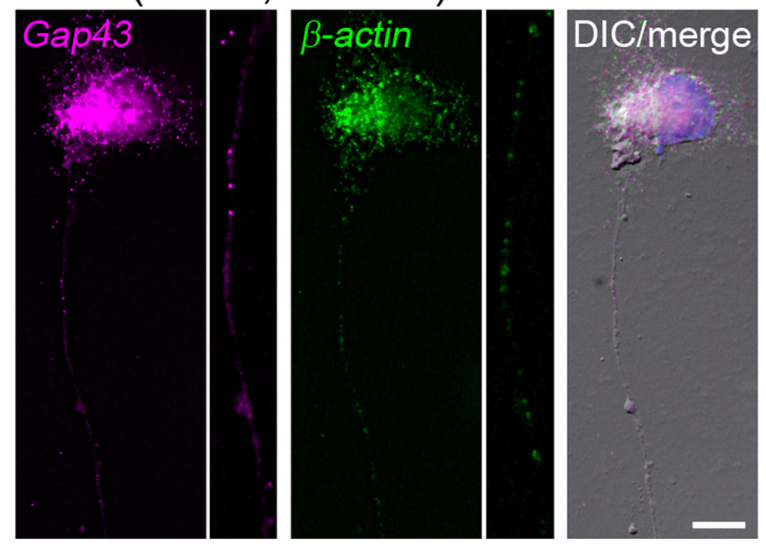

\section{GFP probes No probe}

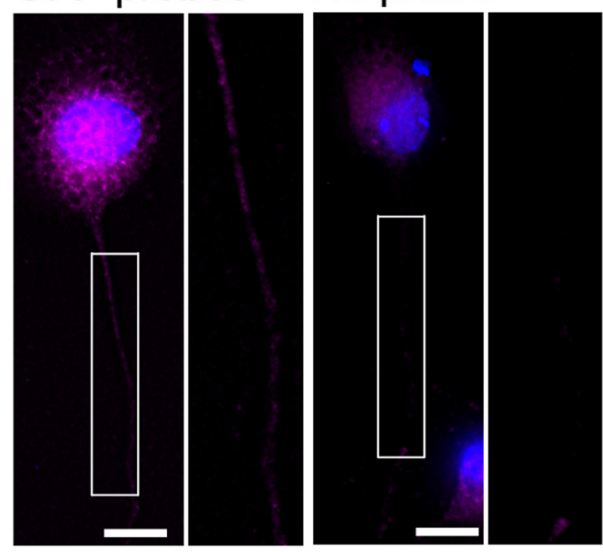

E
D

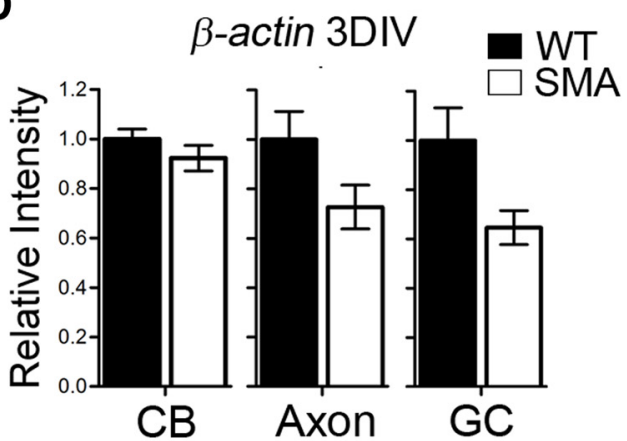

Gap43 3DIV

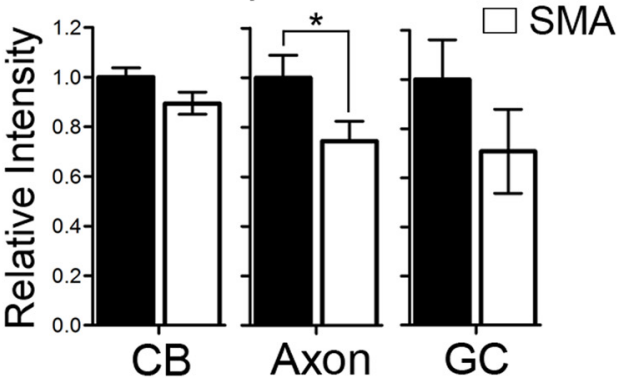

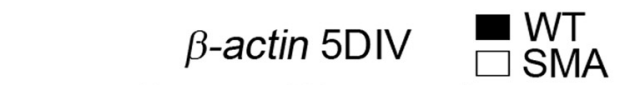

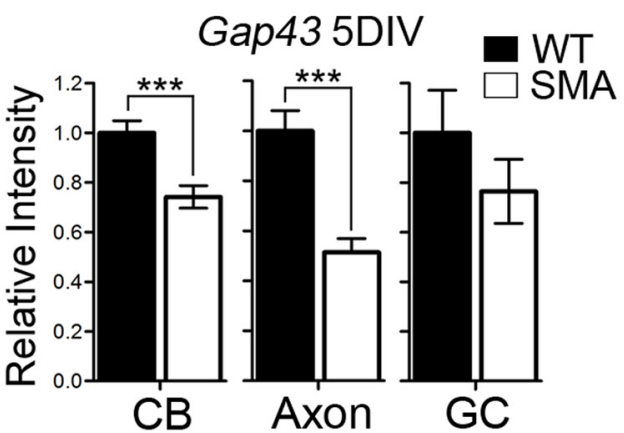

Figure 4. GAP43 mRNA levels are reduced in axons, growth cones, and cell bodies during the development of SMA motor neurons. $\boldsymbol{A}, \boldsymbol{B}, \mathrm{Q}-\mathrm{FISH}$ of $\mathrm{GAP} 43$ (magenta) and $\beta$-actin (green) mRNA in WT and SMA motor neurons. Scale bar, $10 \mu \mathrm{m}$. C, No probe and GFP probes were used as FISH controls. D, E, Quantification of fluorescence intensity in 3 and 5 DIV WT and SMA neurons in the cell body (CB), axon, and growth cone (GC). Error bars indicate mean \pm SEM (Student's $t$ test; $n=45-65$ cells from three independent experiments; ${ }^{*} p<0.05,{ }^{* *} p<$ $\left.0.01,{ }^{* * *} p<0.001\right)$. 


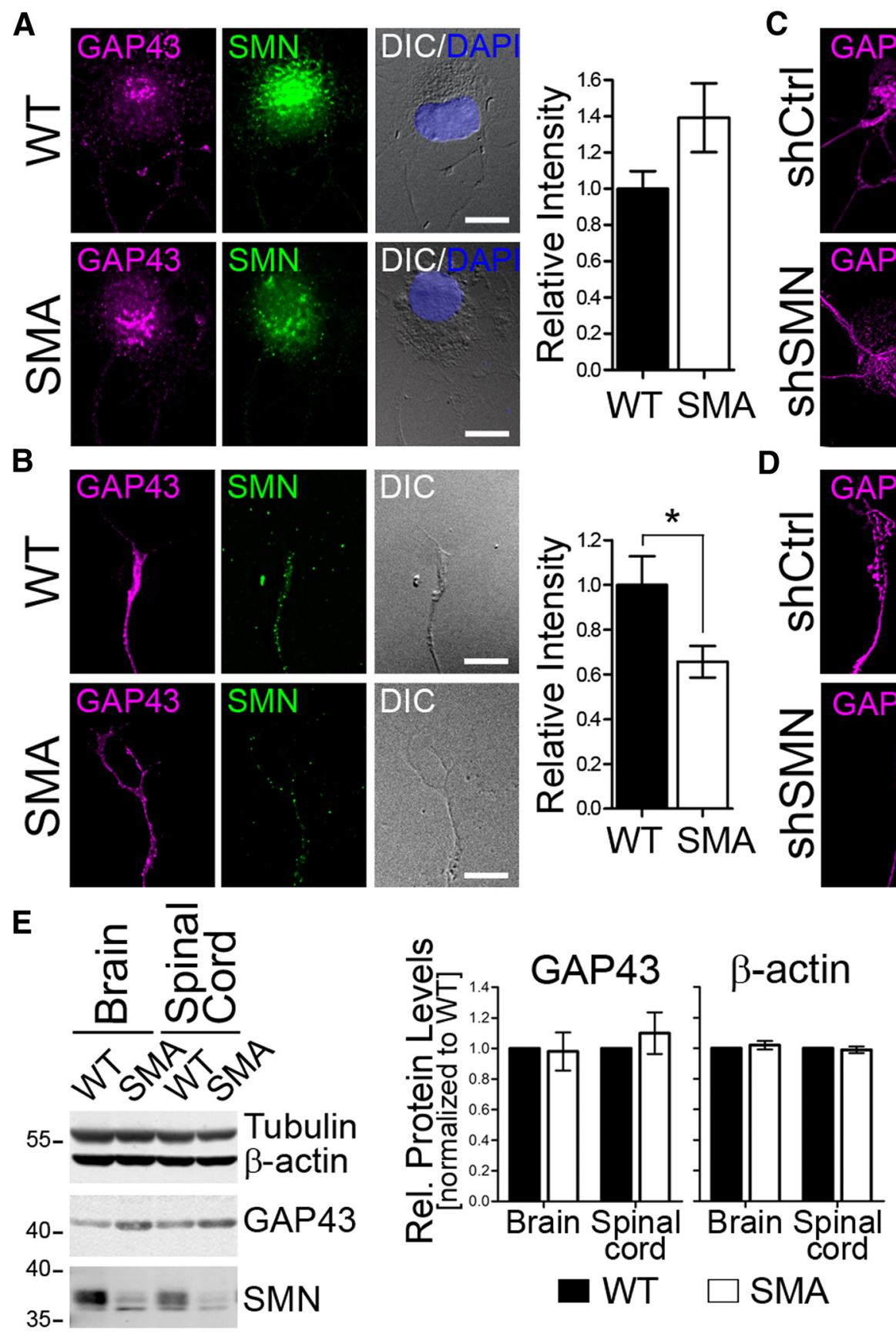

Figure 5. GAP43 protein levels are reduced in axonal growth cones of SMA motor neurons. $\boldsymbol{A}, \boldsymbol{B}$, Immunostaining and quantification of GAP43 levels (magenta) in the cell body $(\boldsymbol{A})$ and growth cone (B) of SMA and WT motor neurons. Error bars indicate mean \pm SEM (Student's $s$ test; $n=43 ;{ }^{*} p<0.05$ ). Scale bar, $10 \mu \mathrm{m}$. C, D, Immunostaining and quantification of GAP43 protein levels (magenta) in the cell body $(\boldsymbol{C})$ and growth cone $(\boldsymbol{D})$ of motor neurons transfected with shRNA constructs. GFP expression (green) was used to identify transfected cells. Error bars indicate mean \pm SEM (Student's $t$ test; $n=40$ cells from three independent experiments; *** $p<0.001$ ). Scale bar, $10 \mu \mathrm{m}$. $\boldsymbol{E}$, Western blot analysis of GAP43 and $\beta$-actin protein levels in SMA tissue. SMN and Tubulin were used as controls. Error bars indicate mean \pm SEM $(n=4)$.

linking SMA pathogenesis to defects in mRNA splicing is still inconclusive. Over the past decade, we and others have demonstrated an additional function for SMN in the regulation of the axonal localization of ribonucleoproteins (mRNPs; Rossoll et al., 2002; Rossoll et al., 2003; Akten et al., 2011; Fallini et al., 2011; Hubers et al., 2011; Fallini et al., 2014). Two mRBPs, HuD (Akten et al., 2011; Fallini et al., 2011; Hubers et al., 2011) and IMP1 (Fallini et al., 2014), have been shown to interact with SMN and to depend on SMN for their axonal localization. Both $\mathrm{HuD}$ and IMP1 bind and control the localization, stability, and transport of, among others, GAP43, $\beta$-actin, tau, and neuritin/cpg15 mR-
NAs (Atlas et al., 2007; Akten et al., 2011; Yoo et al., 2013). SMN deficiency leads to the dysregulation of not one, but several axonal mRNAs, including $\beta$-actin and neuritin/cpg15 (Rossoll and Bassell, 2009; Fallini et al., 2012a; Li et al., 2014). Recent work has further revealed impairments in the local translation of $m T O R$ mRNA in SMA (Kye et al., 2014), suggesting general impairments in local protein synthesis. Here, we analyzed newly synthesized proteins in the cell body and growth cone to show directly that axonal, but not somatic, protein synthesis is reduced in SMA. We further show that in SMA motor neurons the localization of GAP43 mRNA and protein at the growth cone is impaired. 
A
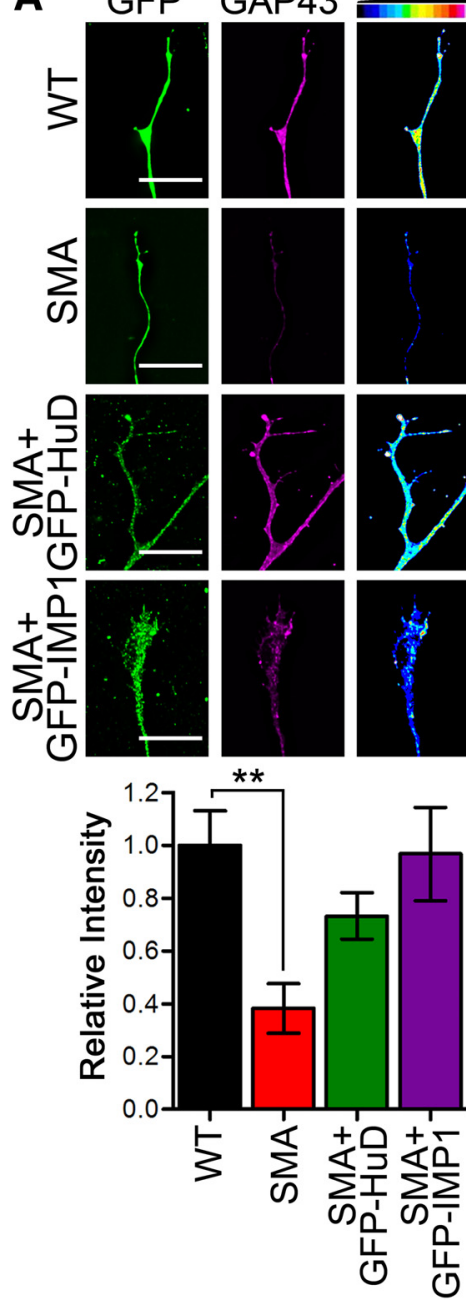

B
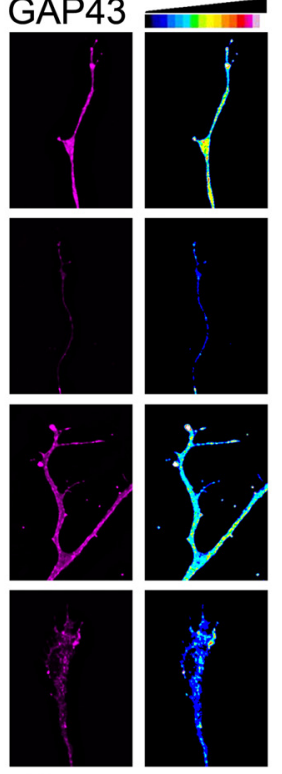

B GFP GAP43 Tubulin C
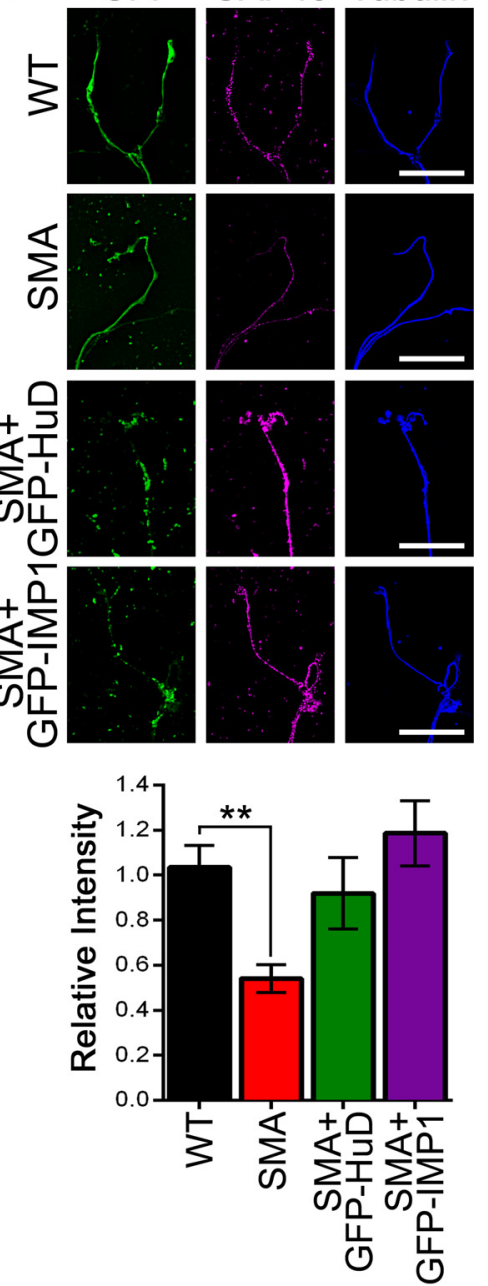
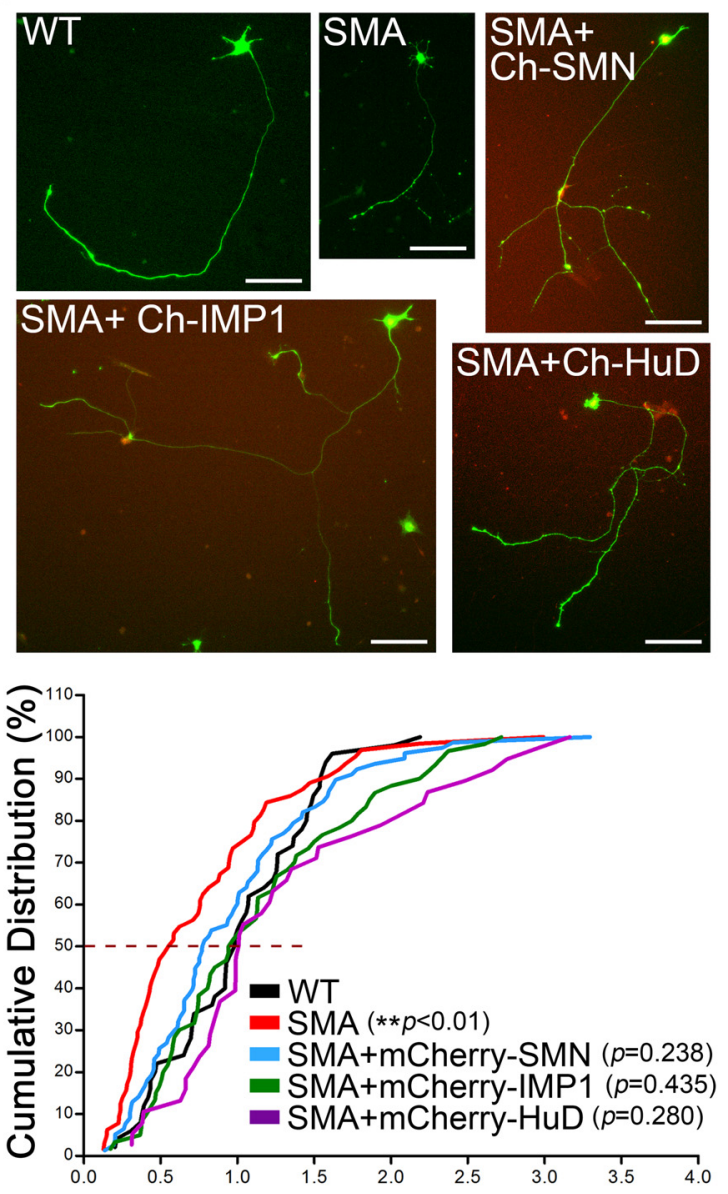

Axon Length

[normalized to WT]

Figure 6. Overexpression of HuD and IMP1 restores GAP43 protein and transcript levels in growth cones, as well as axon outgrowth of SMA motor neurons. $\boldsymbol{A}$, Immunostaining and quantification of GAP43 protein levels (magenta) in WT and SMA motor neurons with or without the expression of GFP-tagged HuD and IMP1 (green). Error bars indicate mean \pm SEM (one-way ANOVA and Dunnett's post hoc test; $n=30$ growth cones from three independent experiments; ${ }^{* *} p<0.01$ ). Scale bars, $10 \mu \mathrm{m}$. $\boldsymbol{B}$, FISH and quantification of GAP43 mRNA levels (magenta) in WT and SMA motor neurons with or without the expression of GFP-tagged HuD and IMP1 (green). Tubulin (blue) was used to label the axons and growth cones. Error bars indicate mean \pm SEM (one-way ANOVA and Dunnett's post hoc test; $n=46-48$ growth cones from three independent experiments; $\left.{ }^{* *} p<0.01\right)$. Scale bars, $10 \mu \mathrm{m}$. $\boldsymbol{C}$, Representative images and cumulative distribution analysis of axonal length of WT and SMA motor neurons with or without the expression of mCherry-tagged SMN, HuD, and IMP1. The $y$-axis represents the frequency of the occurrence of axonal length values equal or less than a reference value. For statistical analysis, the Komogorov-Smirnov test was used ( $n=38-70$ cells from three independent experiments). Scale bars, $50 \mu m$.

GAP43 is of special interest because this growth cone protein plays a key role in regulating growth cone stability and axon growth. GAP43, by stabilizing actin filaments (He et al., 1997), positively regulates neurite growth and pathfinding (Aigner et al., 1995; Strittmatter et al., 1995; Shen et al., 2002; Shen and Meiri, 2013), axon sprouting after injury (Donnelly et al., 2013; Yoo et al., 2013), and the maintenance of synaptic stability (Allegra Mascaro et al., 2013). Motor neurons derived from SMA animal models show impaired axon growth (McWhorter et al., 2003; Rossoll et al., 2003; Winkler et al., 2005; Ymlahi-Ouazzani et al., 2010) and inefficient sprouting (Cifuentes-Diaz et al., 2002; Murray et al., 2008) in response to muscle denervation. Together, these observations point to GAP43 as an intriguing novel target that may underlie axonal growth defects in SMA disease motor neurons. Furthermore, in vivo gene silencing of GAP43 in adult rodent climbing fibers demonstrates that this protein is essential not only during regeneration, but also for maintenance of axons under normal conditions (Grasselli et al., 2011). It is interesting that the mRNAs that have been shown to be misregulated in
SMN-deficient cells, such as GAP43 in the present study and the previously identified $\beta$-actin, tau, and neuritin/cpg15, code for proteins that are involved in the regulation of axonal growth and neuron plasticity during development and regeneration (Denny, 2006; Dent et al., 2011; Zhou and Zhou, 2014), processes that are altered in SMA.

We also show here that the overexpression of two regulatory mRBPs, HuD and IMP1, is sufficient not only to restore GAP43 levels at the growth cone, but also to rescue the axon outgrowth defects observed in SMA motor neurons. Importantly, our data show that local protein synthesis at the distal axon is reduced in SMA neurons, suggesting that GAP43 protein deficiency is due to its reduced $\mathrm{mRNA}$ transport and that $\mathrm{mRBP}$ expression restores GAP43 mRNA localization and local translation. This is further supported by the fact that the local synthesis at the growth cone of the GAP43 mRNA is required to enhance axon growth (Donnelly et al., 2013). Indeed, expression of a chimeric GAP43 mRNA in which the 3'UTR was replaced with a nonlocalizing sequence (i.e., $\gamma$-actin $3^{\prime}$ UTR) was shown to have a minimal effect on axon 
growth (Donnelly et al., 2013). These results provide further support for the hypothesis that SMA is at least partially caused by a disruption in the SMN-dependent regulation of axonal mRNA localization and local translation.

The reduction in the levels of functional SMN protein in motor neurons is associated with the axon-specific downregulation of several transcripts. Recent microarray analyses of axonal mRNAs performed in SMA motor neurons and NSC-34 cells demonstrated that molecular pathways such as synapse function and formation, protein translation, and mRNA binding were particularly affected (Saal et al., 2014). Interestingly, a large percentage of SMN-associated mRNAs are enriched in the axons, supporting $\mathrm{SMN}^{\prime}$ s role in axonal mRNA localization (Rage et al., 2013). Furthermore, these and similar studies suggest that the disruption of a single specific transcript may not lead to an SMA-like phenotype and, similarly, that restoring individual mRNAs may not be sufficient to fully rescue the SMA phenotype (Zhang et al., 2008; Fallini et al., 2011; Saal et al., 2014). Indeed, restoring neuritin/cpg15 mRNA levels in zebrafish SMA motor neurons only partially rescued motor axon defects (Akten et al., 2011 ) and the motor-neuron-specific knock-out of the $\beta$-actin gene had no obvious phenotypic consequences in mice (Cheever et al., 2011). Our approach to attempting a phenotypic rescue via the expression of the regulatory mRBPs in SMA motor neurons was not only able to restore GAP43 mRNA and protein levels, but also fully rescued the defects in motor axon outgrowth observed in SMA motor neurons. This is possibly due to the fact that $\mathrm{HuD}$ and IMP1 regulate the mRNA localization and translation of multiple transcripts encoding SMA-relevant modulators of cytoskeletal dynamics and function. Future work will be required to identify additional transcripts and their relative contribution to the rescue of the axonal phenotype.

Although we cannot exclude that HuD and IMP1 overexpression rescued the observed phenotypes by modulating proposed SMAspecific splicing defects or by affecting SMN2 pre-mRNA splicing, this is unlikely. Both $\mathrm{HuD}$ and IMP1 mRBPs have very limited or no known effect on mRNA splicing and the large majority of $\mathrm{HuD}$ and IMP1 binding sites are located in the $3^{\prime}$ - and $5^{\prime}$-UTRs, rather than intronic sequences (Jønson et al., 2007; Bolognani et al., 2010; Bronicki and Jasmin, 2013). Furthermore, SMN mRNA was not detected as a target of either HuD or IMP1 in large protein-RNA coimmunoprecipitation screenings (Jønson et al., 2007; Bolognani et al., 2010). It appears more likely that SMN, analogous to its function as a chaperone for snRNP biogenesis, is required for the assembly of neuronal mRNA transport complexes (Li et al., 2014). Further studies will be needed to investigate whether $\mathrm{HuD}$ and IMP1 overexpression can mitigate SMN-dependent defects in mRNP assembly. One possibility is that $\mathrm{HuD}$ and IMP1 overexpression may efficiently compete with other SMN binding partners, leading to a net increase in the number of assembled mRNP complexes and thus enhancing transport and local translation of GAP43 and possibly other axonal mRNAs.

In conclusion, our study supports a model whereby SMN depletion affects the ability of mRBPs to transport and enhance the local translation of several mRNAs. This suggests that, collectively, their deficiency may contribute to axon degeneration, muscle denervation, and motor neuron death in SMA.

\section{References}

Aigner L, Arber S, Kapfhammer JP, Laux T, Schneider C, Botteri F, Brenner HR, Caroni P (1995) Overexpression of the neural growth-associated protein GAP-43 induces nerve sprouting in the adult nervous system of transgenic mice. Cell 83:269-278. CrossRef Medline

Akten B, Kye MJ, Hao le T, Wertz MH, Singh S, Nie D, Huang J, Merianda TT, Twiss JL, Beattie CE, Steen JA, Sahin M (2011) Interaction of survival of motor neuron (SMN) and HuD proteins with mRNA cpg15 rescues motor neuron axonal deficits. Proc Natl Acad Sci U S A 108:10337-10342. CrossRef Medline

Allegra Mascaro AL, Cesare P, Sacconi L, Grasselli G, Mandolesi G, Maco B, Knott GW, Huang L, De Paola V, Strata P, Pavone FS (2013) In vivo single branch axotomy induces GAP-43-dependent sprouting and synaptic remodeling in cerebellar cortex. Proc Natl Acad Sci U S A 110:1082410829. CrossRef Medline

Atlas R, Behar L, Sapoznik S, Ginzburg I (2007) Dynamic association with polysomes during P19 neuronal differentiation and an untranslatedregion-dependent translation regulation of the tau mRNA by the tau mRNA-associated proteins IMP1, HuD, and G3BP1. J Neurosci Res 85: 173-183. CrossRef Medline

Azzouz TN, Pillai RS, Däpp C, Chari A, Meister G, Kambach C, Fischer U, Schümperli D (2005) Toward an assembly line for U7 snRNPs: interactions of U7-specific Lsm proteins with PRMT5 and SMN complexes. J Biol Chem 280:34435-34440. CrossRef Medline

Battle DJ, Kasim M, Yong J, Lotti F, Lau CK, Mouaikel J, Zhang Z, Han K, Wan L, Dreyfuss G (2006) The SMN complex: an assembly machine for RNPs. Cold Spring Harb Symp Quant Biol 71:313-320. CrossRef Medline

Bolognani F, Contente-Cuomo T, Perrone-Bizzozero NI (2010) Novel recognition motifs and biological functions of the RNA-binding protein $\mathrm{HuD}$ revealed by genome-wide identification of its targets. Nucleic Acids Res 38:117-130. CrossRef Medline

Boulisfane N, Choleza M, Rage F, Neel H, Soret J, Bordonné R (2011) Impaired minor tri-snRNP assembly generates differential splicing defects of U12-type introns in lymphoblasts derived from a type I SMA patient. Hum Mol Genet 20:641-648. CrossRef Medline

Brahms H, Meheus L, de Brabandere V, Fischer U, Lührmann R (2001) Symmetrical dimethylation of arginine residues in spliceosomal Sm protein $\mathrm{B} / \mathrm{B}^{\prime}$ and the Sm-like protein LSm4, and their interaction with the SMN protein. RNA 7:1531-1542. CrossRef Medline

Bronicki LM, Jasmin BJ (2013) Emerging complexity of the HuD/ELAVl4 gene; implications for neuronal development, function, and dysfunction. RNA 19:1019-1037. CrossRef Medline

Cheever TR, Olson EA, Ervasti JM (2011) Axonal regeneration and neuronal function are preserved in motor neurons lacking ss-actin in vivo. PLoS One 6:e17768. CrossRef Medline

Cifuentes-Diaz C, Nicole S, Velasco ME, Borra-Cebrian C, Panozzo C, Frugier T, Millet G, Roblot N, Joshi V, Melki J (2002) Neurofilament accumulation at the motor endplate and lack of axonal sprouting in a spinal muscular atrophy mouse model. Hum Mol Genet 11:1439-1447. CrossRef Medline

Coady TH, Lorson CL (2011) SMN in spinal muscular atrophy and snRNP biogenesis. Wiley Interdiscip Rev RNA 2:546-564. CrossRef Medline

Crawford TO, Pardo CA (1996) The neurobiology of childhood spinal muscular atrophy. Neurobiol Dis 3:97-110. CrossRef Medline

Denny JB (2006) Molecular mechanisms, biological actions, and neuropharmacology of the growth-associated protein GAP-43. Curr Neuropharmacol 4:293-304. CrossRef Medline

Dent EW, Gupton SL, Gertler FB (2011) The growth cone cytoskeleton in axon outgrowth and guidance. Cold Spring Harb Perspect Biol 3.

Donnelly CJ, Park M, Spillane M, Yoo S, Pacheco A, Gomes C, Vuppalanchi D, McDonald M, Kim HK, Merianda TT, Gallo G, Twiss JL (2013) Axonally synthesized beta-actin and GAP-43 proteins support distinct modes of axonal growth. J Neurosci 33:3311-3322. CrossRef Medline

Dupuis L, Echaniz-Laguna A (2010) Skeletal muscle in motor neuron diseases: therapeutic target and delivery route for potential treatments. Curr Drug Targets 11:1250-1261. CrossRef Medline

Fallini C, Bassell GJ, Rossoll W (2010) High-efficiency transfection of cultured primary motor neurons to study protein localization, trafficking, and function. Mol Neurodegener 5:17. CrossRef Medline

Fallini C, Zhang H, Su Y, Silani V, Singer RH, Rossoll W, Bassell GJ (2011) The survival of motor neuron (SMN) protein interacts with the mRNAbinding protein $\mathrm{HuD}$ and regulates localization of poly(A) mRNA in primary motor neuron axons. J Neurosci 31:3914-3925. CrossRef Medline

Fallini C, Bassell GJ, RossollW (2012a) Spinal muscular atrophy: the role of SMN in axonal mRNA regulation. Brain Res 1462:81-92. CrossRef Medline

Fallini C, Bassell GJ, Rossoll W (2012b) The ALS disease protein TDP-43 is actively transported in motor neuron axons and regulates axon outgrowth. Hum Mol Genet 21:3703-3718. CrossRef Medline 
Fallini C, Rouanet JP, Donlin-Asp PG, Guo P, Zhang H, Singer RH, Rossoll W, Bassell GJ (2014) Dynamics of survival of motor neuron (SMN) protein interaction with the mRNA-binding protein IMP1 facilitates its trafficking into motor neuron axons. Dev Neurobiol 74:319-332. CrossRef Medline

Friesen WJ, Dreyfuss G (2000) Specific sequences of the Sm and Sm-like (Lsm) proteins mediate their interaction with the spinal muscular atrophy disease gene product (SMN). J Biol Chem 275:26370-26375. CrossRef Medline

Goulet BB, Kothary R, Parks RJ (2013) At the "junction" of spinal muscular atrophy pathogenesis: the role of neuromuscular junction dysfunction in SMA disease progression. Curr Mol Med 13:1160-1174. CrossRef Medline

Grasselli G, Mandolesi G, Strata P, Cesare P (2011) Impaired sprouting and axonal atrophy in cerebellar climbing fibres following in vivo silencing of the growth-associated protein GAP-43. PLoS One 6:e20791. CrossRef Medline

Gubitz AK, Feng W, Dreyfuss G (2004) The SMN complex. Exp Cell Res 296:51-56. CrossRef Medline

He Q, Dent EW, Meiri KF (1997) Modulation of actin filament behavior by GAP-43 (neuromodulin) is dependent on the phosphorylation status of serine 41, the protein kinase C site. J Neurosci 17:3515-3524. Medline

Hubers L, Valderrama-Carvajal H, Laframboise J, Timbers J, Sanchez G, Côté J (2011) HuD interacts with survival motor neuron protein and can rescue spinal muscular atrophy-like neuronal defects. Hum Mol Genet 20:553-579. CrossRef Medline

Jønson L, Vikesaa J, Krogh A, Nielsen LK, Hansen Tv, Borup R, Johnsen AH, Christiansen J, Nielsen FC (2007) Molecular composition of IMP1 ribonucleoprotein granules. Mol Cell Proteomics 6:798-811. CrossRef Medline

Kariya S, Park GH, Maeno-Hikichi Y, Leykekhman O, Lutz C, Arkovitz MS, Landmesser LT, Monani UR (2008) Reduced SMN protein impairs maturation of the neuromuscular junctions in mouse models of spinal muscular atrophy. Hum Mol Genet 17:2552-2569. CrossRef Medline

Kye MJ, Niederst ED, Wertz MH, Gonçalves Ido C, Akten B, Dover KZ, Peters M, Riessland M, Neveu P, Wirth B, Kosik KS, Sardi SP, Monani UR, Passini MA, Sahin M (2014) SMN regulates axonal local translation via miR-183/mTOR pathway. Hum Mol Genet 23:6318-6331. CrossRef Medline

Lefebvre S, Bürglen L, Reboullet S, Clermont O, Burlet P, Viollet L, Benichou B, Cruaud C, Millasseau P, Zeviani M, Le Paslier D, Frézal J, Cohen D, Weissenbach J, Munnich A, Melki J (1995) Identification and characterization of a spinal muscular atrophy-determining gene. Cell 80:155-165. CrossRef Medline

Li DK, Tisdale S, Lotti F, Pellizzoni L (2014) SMN control of RNP assembly: From post-transcriptional gene regulation to motor neuron disease. Semin Cell Dev Biol 32:22-29. CrossRef Medline

Ling KK, Lin MY, Zingg B, Feng Z, Ko CP (2010) Synaptic defects in the spinal and neuromuscular circuitry in a mouse model of spinal muscular atrophy. PLoS One 5:e15457. CrossRef Medline

Ling KK, Gibbs RM, Feng Z, Ko CP (2012) Severe neuromuscular denervation of clinically relevant muscles in a mouse model of spinal muscular atrophy. Hum Mol Genet 21:185-195. CrossRef Medline

Lotti F, Imlach WL, Saieva L, Beck ES, Hao le T, Li DK, Jiao W, Mentis GZ, Beattie CE, McCabe BD, Pellizzoni L (2012) An SMN-dependent U12 splicing event essential for motor circuit function. Cell 151:440-454. CrossRef Medline

Martinez TL, Kong L, Wang X, Osborne MA, Crowder ME, Van Meerbeke JP, Xu X, Davis C, Wooley J, Goldhamer DJ, Lutz CM, Rich MM, Sumner CJ (2012) Survival motor neuron protein in motor neurons determines synaptic integrity in spinal muscular atrophy. J Neurosci 32:8703-8715. CrossRef Medline

McWhorter ML, Monani UR, Burghes AH, Beattie CE (2003) Knockdown of the survival motor neuron (Smn) protein in zebrafish causes defects in motor axon outgrowth and pathfinding. J Cell Biol 162:919-931. CrossRef Medline

Monani UR, Sendtner M, Coovert DD, Parsons DW, Andreassi C, Le TT, Jablonka S, Schrank B, Rossol W, Prior TW, Morris GE, Burghes AH (2000) The human centromeric survival motor neuron gene (SMN2) rescues embryonic lethality in $\mathrm{Smn}(-/-)$ mice and results in a mouse with spinal muscular atrophy. Hum Mol Genet 9:333-339. CrossRef Medline

Murray LM, Comley LH, Thomson D, Parkinson N, Talbot K, Gillingwater TH (2008) Selective vulnerability of motor neurons and dissociation of pre- and post-synaptic pathology at the neuromuscular junction in mouse models of spinal muscular atrophy. Hum Mol Genet 17:949-962. Medline

Pellizzoni L (2007) Chaperoning ribonucleoprotein biogenesis in health and disease. ЕMBO Rep 8:340-345. CrossRef Medline

Rage F, Boulisfane N, Rihan K, Neel H, Gostan T, Bertrand E, Bordonné R, Soret J (2013) Genome-wide identification of mRNAs associated with the protein SMN whose depletion decreases their axonal localization. RNA 19:1755-1766. CrossRef Medline

Rossoll W, Bassell GJ (2009) Spinal muscular atrophy and a model for survival of motor neuron protein function in axonal ribonucleoprotein complexes. Results Probl Cell Differ 48:289-326. Medline

Rossoll W, Kröning AK, Ohndorf UM, Steegborn C, Jablonka S, Sendtner M (2002) Specific interaction of Smn, the spinal muscular atrophy determining gene product, with hnRNP-R and gry-rbp/hnRNP-Q: a role for Smn in RNA processing in motor axons? Hum Mol Genet 11:93-105. CrossRef Medline

Rossoll W, Jablonka S, Andreassi C, Kröning AK, Karle K, Monani UR, Sendtner M (2003) Smn, the spinal muscular atrophy-determining gene product, modulates axon growth and localization of beta-actin mRNA in growth cones of motoneurons. J Cell Biol 163:801-812. CrossRef Medline

Ruiz R, Tabares L (2014) Neurotransmitter release in motor nerve terminals of a mouse model of mild spinal muscular atrophy. J Anat 224:74-84. CrossRef Medline

Saal L, Briese M, Kneitz S, Glinka M, Sendtner M (2014) Subcellular transcriptome alterations in a cell culture model of spinal muscular atrophy point to widespread defects in axonal growth and presynaptic differentiation. RNA 20:1789-1802. CrossRef Medline

Sanchez G, Dury AY, Murray LM, Biondi O, Tadesse H, El Fatimy R, Kothary R, Charbonnier F, Khandjian EW, Côté J (2013) A novel function for the survival motoneuron protein as a translational regulator. Hum $\mathrm{Mol}$ Genet 22:668-684. CrossRef Medline

Shen Y, Meiri K (2013) GAP-43 dependency defines distinct effects of netrin-1 on cortical and spinal neurite outgrowth and directional guidance. Int J Dev Neurosci 31:11-20. CrossRef Medline

Shen Y, Mani S, Donovan SL, Schwob JE, Meiri KF (2002) Growthassociated protein- 43 is required for commissural axon guidance in the developing vertebrate nervous system. J Neurosci 22:239-247. Medline

Smith CL, Afroz R, Bassell GJ, Furneaux HM, Perrone-Bizzozero NI, Burry RW (2004) GAP-43 mRNA in growth cones is associated with $\mathrm{HuD}$ and ribosomes. J Neurobiol 61:222-235. CrossRef Medline

Strittmatter SM, Fankhauser C, Huang PL, Mashimo H, Fishman MC (1995) Neuronal pathfinding is abnormal in mice lacking the neuronal growth cone protein GAP-43. Cell 80:445-452. CrossRef Medline

Tisdale S, Lotti F, Saieva L, Van Meerbeke JP, Crawford TO, Sumner CJ, Mentis GZ, Pellizzoni L (2013) SMN is essential for the biogenesis of U7 small nuclear ribonucleoprotein and $3^{\prime}$-end formation of histone mRNAs. Cell Rep 5:1187-1195. CrossRef Medline

Tom Dieck S, Muller A, Nehring A, Hinz FI, Bartnik I, Schuman EM, Dieterich DC (2012) Metabolic labeling with noncanonical amino acids and visualization by chemoselective fluorescent tagging. Curr Protoc Cell Biol Chapter 7:Unit7.11. CrossRef Medline

Winkler C, Eggert C, Gradl D, Meister G, Giegerich M, Wedlich D, Laggerbauer B, Fischer U (2005) Reduced U snRNP assembly causes motor axon degeneration in an animal model for spinal muscular atrophy. Genes Dev 19:2320-2330. CrossRef Medline

Workman E, Kolb SJ, Battle DJ (2012) Spliceosomal small nuclear ribonucleoprotein biogenesis defects and motor neuron selectivity in spinal muscular atrophy. Brain Res 1462:93-99. CrossRef Medline

Ymlahi-Ouazzani Q, J Bronchain O, Paillard E, Ballagny C, Chesneau A, Jadaud A, Mazabraud A, Pollet N (2010) Reduced levels of survival motor neuron protein leads to aberrant motoneuron growth in a Xenopus model of muscular atrophy. Neurogenetics 11:27-40. CrossRef Medline

Yoo S, Kim HH, Kim P, Donnelly CJ, Kalinski AL, Vuppalanchi D, Park M, Lee SJ, Merianda TT, Perrone-Bizzozero NI, Twiss JL (2013) A HuDZBP1 ribonucleoprotein complex localizes GAP-43 mRNA into axons through its $3^{\prime}$ untranslated region AU-rich regulatory element. J Neurochem 126:792-804. CrossRef Medline

Zhang Z, Lotti F, Dittmar K, Younis I, Wan L, Kasim M, Dreyfuss G (2008) SMN deficiency causes tissue-specific perturbations in the repertoire of snRNAs and widespread defects in splicing. Cell 133:585-600. CrossRef Medline

Zhou S, Zhou J (2014) Neuritin, a neurotrophic factor in nervous system physiology. Curr Med Chem 21:1212-1219. CrossRef Medline 